原

進行胃癌の原発巣及び同転移リンパ節に打けるDNA

ploidy pattern, proliferation index および Proliferating

cell nuclear antigen (PCNA) の検討

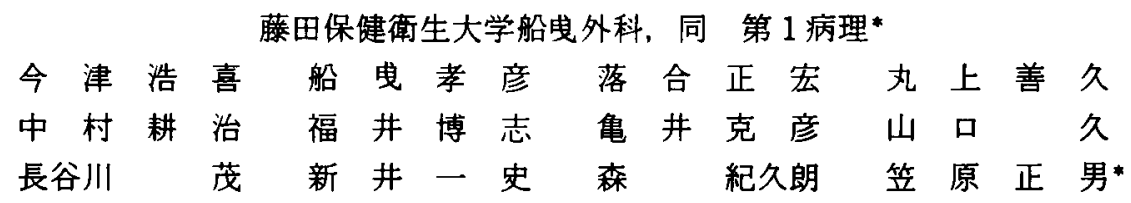

リンハ節転移を伴5進行胃癌15症例55標本を用いて原発巣と各群所属リンパ節の， DNA ploidy pattern, PI, および PCNA を測定し，バラメータ間の相関を検討, PCNA についてはホルマリン固定期間と染色率の相関を検討した。さらに転移りンハ節におい ては, 近傍, 遠位への転移と, heterogeneityについても検討した。結果：(1)原発巣及び 転移リンパ節55標本中78\% (43標本) が DNA aneuploidy patternを示した. (2) 8 症例 （53\%）にDNA histogram 上 heterogeneity が認められた。 (3) PCNA 染色は55標本中 96\%（53標本）の染色陽性率で，畽場巣に打いては唡漫性に染色陽性に認められた。 (4) DNA aneuploidy pattern の標本に有意に PI $(p<0.05)$, PCNA 陽性率 $(p<0.005)$ か

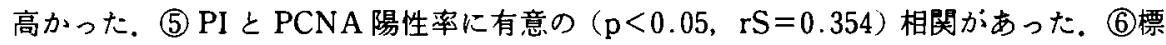
本のホルマリン固定期間は 2 週間以内では PCNA 陽性率に有意な影響を与えなかべた $(\mathrm{rS}=0.128)$. (7)原発宩, 転移リンパ節 $\mathrm{n} 1, \mathrm{n} 2, \mathrm{n} 3-4$ の各群間においてその DNA ploidy pattern, PI, PCNA 陽性率の全てに有意差はなかった。 以上の結果から，より遠位のリ ンバ節に転移することと、これらバラィータによる悪性度, 増殖能との関連は証明しえ ず,これには heterogeneity が関与していることが考えられた。

索引用語：DNA ploidy pattern, heterogeneity, proliferation index, PCNA, primary and metastatic tumors in advanced gastric carcinoma

緒言

近年,フローサイトメトリー (flow cytometry: FCM)を用いた DNA ploidy pattern p proliferation index (PI)の解析において, DNA aneuploidy 症例や PIの大きな症例は予後が不良であるとの報告があ る ${ }^{1 \sim 4}$. 一方, 同一畽瘍内において核 DNA 量に heterogeneity が存在し, DNA diploidy pattern $と$ DNA aneuploidy pattern の異なった ploidy patternがみら れるとの報告む認められるようになっだ) 名．今回著 者らは，進行胃癌及び同，転移陽性リンパ節群を用い， 原発果と各群所属リンパ節の, DNA ploidy pattern, PI, おょび proliferating cell nuclear antigen(PCNA)

1992年12月16日受付 1993年 6 月23日採用
を測定しその各々のパラィータ間の相関を娭討， PCNA については，ホルマリン固定期間と染色率につ いてもその相関を検討した，さらに転移リンバ節にお いては，所属リンパ節を原発巣に対して，近傍から遠 位へ転移する際, heterogeneityにどのよらな影響が みられるかについても挨討した。

材料

外科的切除後 2 週間以内, $10 \%$ 緩衝ホルマリンにて 固定，ハシラフィン包埋された進行胃癌及び同転移リン ハ節群15症例55標本を用いた。

方 法

1. FCM

細胞核抽出はSchutte-Vindel $\phi \mathrm{v}$ 法 ${ }^{10111}$ を改変した 田川ら ${ }^{21}$ の方法に準じたすなわち, 各ハラフィン包埋 


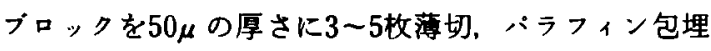
器を用い約24時間，キシレンおよびェタノール列にて 脱ハシラフィン，親水し， citrate buffer trypsin (citric acid $882.3 \mathrm{mg}+$ spermine $522.3 \mathrm{mg}+$ tris $60.6 \mathrm{mg}+$ trypsin (1:250) $2.5 \mathrm{~g}+\mathrm{NP}-401.0 \mathrm{ml}+\mathrm{DW} 1,000-\alpha$ $\mathrm{ml}, \mathrm{pH} 7.6)$ 液 $3 \mathrm{ml}$ を加えた試験管に移し, $37^{\circ} \mathrm{C}$ waterbath, 振盪数 100 回/ $\mathrm{min}, 12 \sim 16$ 時間 incubate 後, 50 $\mu \mathrm{m}$ ナイロンメッシュでろ過，先細試験管に移し， 1,500回転，15分遠沈，上清を捨て, citrate buffer (sucrose $85.5 \mathrm{~g}+$ citric acid $11.8 \mathrm{~g}+$ DSMO $50 \mathrm{ml}+$ DW 1000- $\alpha \mathrm{ml}, \mathrm{pH} 7.6) 200 \mu \mathrm{l}$ を注ざ、ピベッティ ングし試験管に移した後，15分間隔で solution A (trypsin $15 \mathrm{mg}+$ stock solution $500 \mathrm{ml}, \mathrm{pH} 7.6$ ) 1.8 $\mathrm{ml}$, solution B (trypsin inhibitor $250 \mathrm{mg}+\mathrm{RNase} A$ $50 \mathrm{mg}+$ stock solution $500 \mathrm{ml}, \mathrm{pH} 7.6) 1.5 \mathrm{ml}$, solution $\mathrm{C}$ (propidium iodide $208 \mathrm{mg}+$ spermine $580 \mathrm{mg}+$ stock solution $500 \mathrm{ml}, \mathrm{pH} 7.6) 1.5 \mathrm{ml}$ を順次添加し た. [stock solution : citric acid $2,000 \mathrm{ml}+$ spermine $1.044 \mathrm{mg}+$ tris $121 \mathrm{mg}+\mathrm{NP} \cdot 402 \mathrm{ml}+\mathrm{DW} 2000-\alpha \mathrm{ml}]$

FACS440 (Becton Dickinson 社製)にて細胞40,000 個を測定し,DNA histogramを求めた. Internal standard として同一腫啺標本の正常リンパ節 (非転移)を 同様に処理し，その first peak channel numberにて 腫湯細胞の first peak channel numberを除し, DNA index (DI) とした.

1. DNA ploidy pattern

得られた DNA histogram の平均 coefficient variation (CV) 値は7.0\%であり，DNA ploidy patternの 判定には各標本の CV 值, DI 及び histogram より

(1) $\mathrm{DI}<1+(\mathrm{CV} / 100 \times 2)$

(2) $1-(\mathrm{CV} / 100 \times 2)<\mathrm{DI}$

(3) $2 \mathrm{C}, 4 \mathrm{C}$ に相当する以外の異常な peak channel を呈するもの

以上(1) (3)の DNA histogramを呈するものを DNA aneuploidy と判定した.

\section{PI 值}

DNA histogram から Kawamoto $ら^{13)}$ の方法にて 増殖期細胞数を測定 $L, P I(\%)=\left(\left(S+G_{2} M\right) /\left(G_{0}\right.\right.$ $\left.\left.\mathrm{G}_{1}+\mathrm{S}+\mathrm{G}_{2} \mathrm{M}\right)\right) \times 100 に$ 算出した。

\section{PCNA}

ハラフィン包埋組織から切片 $(3 \mu \mathrm{m})$ を作成，組織 伸展は湯伸展をせずに短時間で行い未染摽本を作成し た. Avidin-biotin peroxidase complex (ABC) 法 (Vectastain ABC Kit. Vector Lab. USA) を用い,
抗 PCNA 抗体 (New Castle ; Monoclonal antibody) にて反応，染色を行った。顕徽鏡下にその核染色の強 弱にかかわらず，染色されていたものを陽性亡し，標 本内で陽性細胞の分布に著しい隔たりがあるものにつ いては，陽性細胞がもっとも多いと考えられた領域で 細胞300個中の陽性細胞数を算定し，陽性率を求めた。 険定方法は独立 2 群間の差についてはMannWhitney 検定，関連 2 群間の相関についてはSpearman の順位相関係数を, 独立多群間の差については一 元配置分散分析法にて行い，危険率 $5 \%$ 以下を有意の 相関ありとした。

\section{結果}

原発笨及び転移リンパ節の55標本 43 標本 $(78 \%) か ゙$ DNA aneuploidy patternを示した (Table 1). 各症 例について，原発巣とリンハ節転移巣の DNA histogramを比較すると, 原発巣が DNA diploidy pattern にもかかからず転移リンパ節において DNA diploidy 及び aneuploidy patternの両 histogram がみられる など15症例中 8 症例 $(53 \%)$ の転移リンパ節にその原 発巣と異なる DNA ploidy pattern が得られ，原発笨 における heterogeneityを反映したものと考えられた

(Fig. 1, 2).

PCNA 染色は55標本中 $96 \%$ (53標本) に陽性であっ た.PCNA 染色陽性症例ではその原発巣において，良 性胃粘膜部分ではその增殖帯細胞にのみ染色されたの に対して，腫瘍单においては灀漫性に陽性細胞が認め られた (Fig. 3).

1. 各パラメーター間の相関

a) DNA ploidy pattern と PI の相関

DNA ploidy pattern と PIを比較すると, DNA ploidy pattern標本群に比較してDNA aneuploidy

Table 1 DNA histograms of primary gastric carcinoma and lymph nodes metastasis

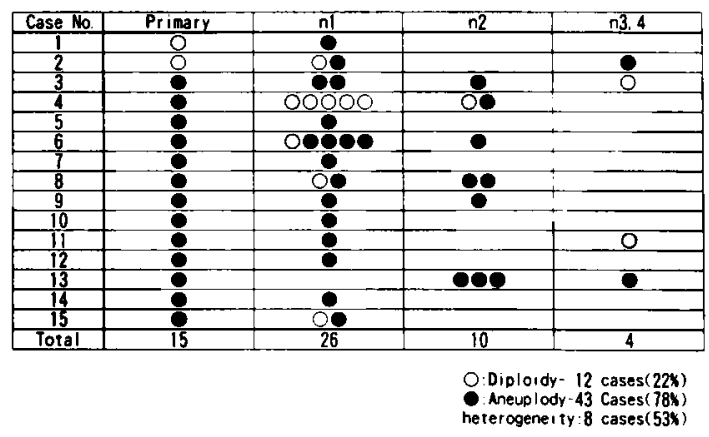


DNA diploid pattern LN
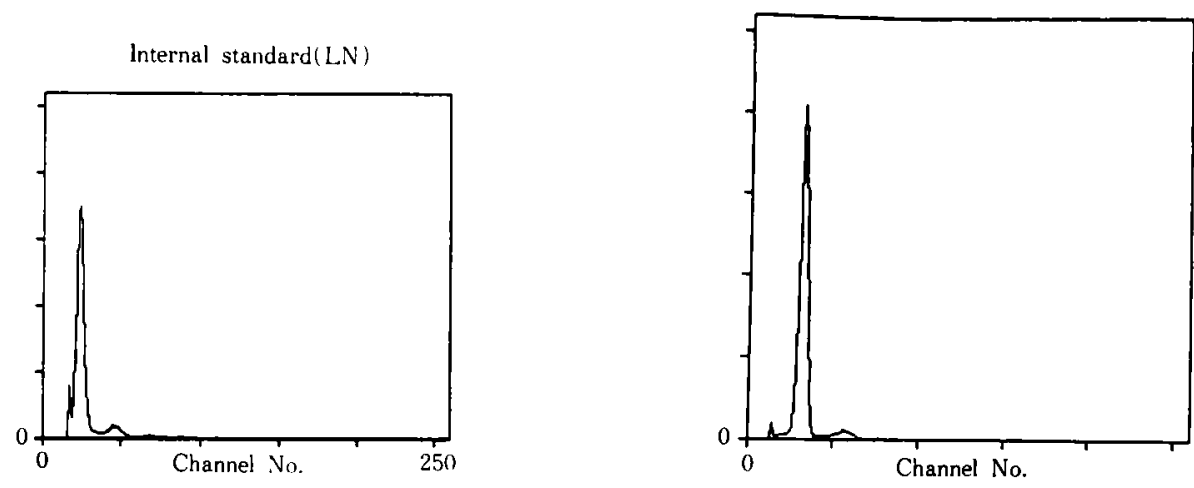

Primary(DNA aneuploid pattern)

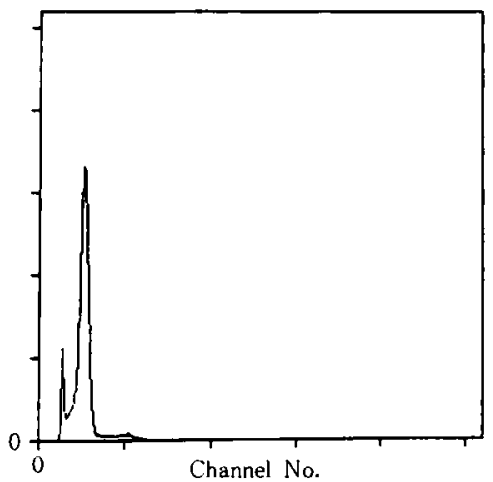

DNA aneuploid pattern LN

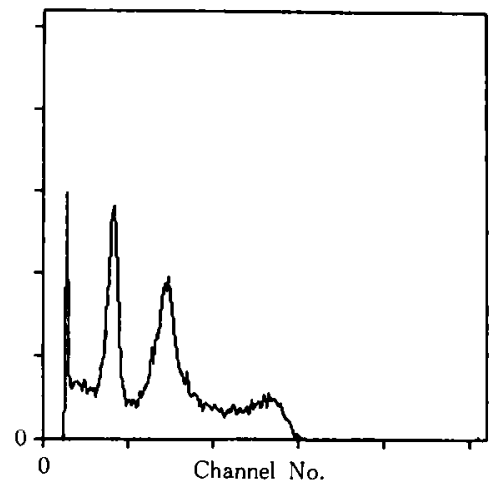

Fig. 1 DNA histogram (primary-DNA diploid pattern, Case 2)

pattern 標本群に有意 $(\mathrm{p}<0.05)$ に PI が高い傾向が認 めら机た Fig. 4 \%。

b , DNA ploidy pattern と PCNA 陽性率の相関

DNA ploidy pattern と PCNA 陽性率とを比較する と, DNA ploidy pattern 標本群に比へ, DNA aneuploidy pattern 標本群に有意 $(p<0.005)$ にCNA 陽 性率が高かった（Fig. 5)。

c) PI \& PCNA 陽性率の相関

PI と PCNA 陽性率を比較すると，有意の( $\mathrm{p}<0.05$ ， $\mathrm{rS}=0.354)$ 相関があり，PIの高い標本はPCNA 陽性 率も高かった（Fig. 6)

2. ホルマリン固定期間と PCNA 染色率の相関

PI 10\%以上の標本で，ホルマリン固定期間と PCNA 陽性率との相関を検討した，光顕的には固定期 間が 3 4 日を越穴ると核染色の程度が淡くなり，染 色の判定が困難になる傾向があったが，染色程度の強 弱にかかわら才染色さ机ていたものを陽性とした場 台，2週間以内では固定期間による陽性率の有意な低
下は見られなかった（rS=0.128，Fig.7）。

3. リンパ節遠隔転移と各パラメータとの相関

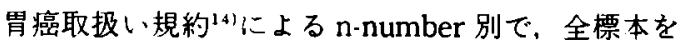
原発巣，n1，n2，n3-4の4群に分けて検討すると，各 群間においてその DNA ploidy pattern, PI(Fig. 8)， PCNA 陽性率（Fig. 9）の全てに有意な相関はみられ なかった。

\section{考察}

近年, ホルマリン固定, ハラフィン包埋標本に対し て，新鮮標本と同様に腫煌細胞の悪性度の判定に FCMによるDNA histogramの解析，検討が行われ， 報告されている。しかし，多くの報告はその得られた histogram $の$ DNA histogram patternに着目した DNA ploidy pattern DIの判定が主体となってお り，その腫湯細胞の増殖能からみた悪性度の評価は余 り行わ机ていない，今回著者らは，進行胃癌のリンハ 節転移に対して，この腫瘍細胞增殖能からみた検討を PI 及び PCNA を用いて行い，リンパ節遠隔転移と腫 
DNA diploid pattern LN
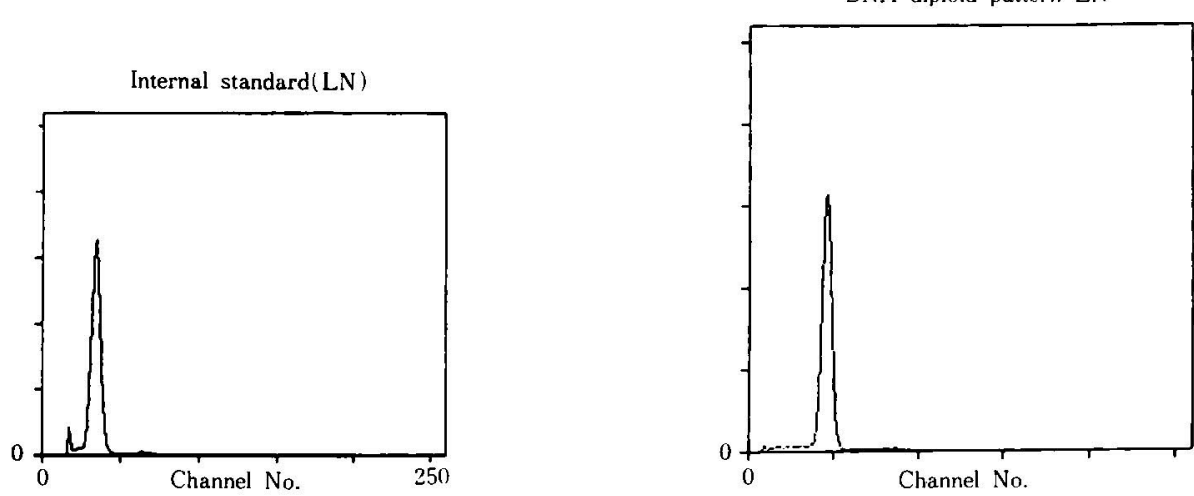

Primary(DNA aneuploid pattern)

DNA aneuploid pattern LN
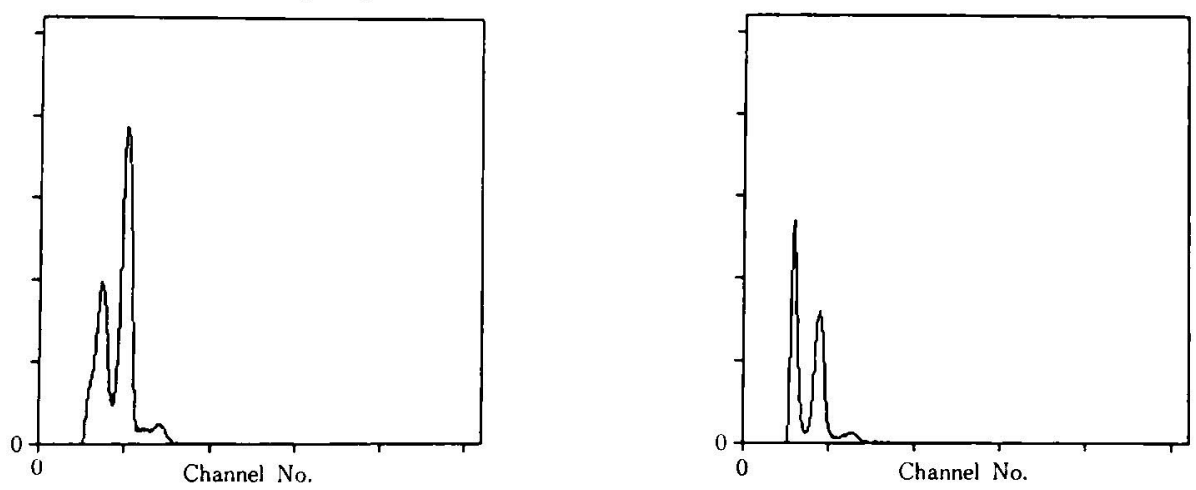

Fig. 2 DNA histogram (primary.DNA aneuploid pattern, Case 3)

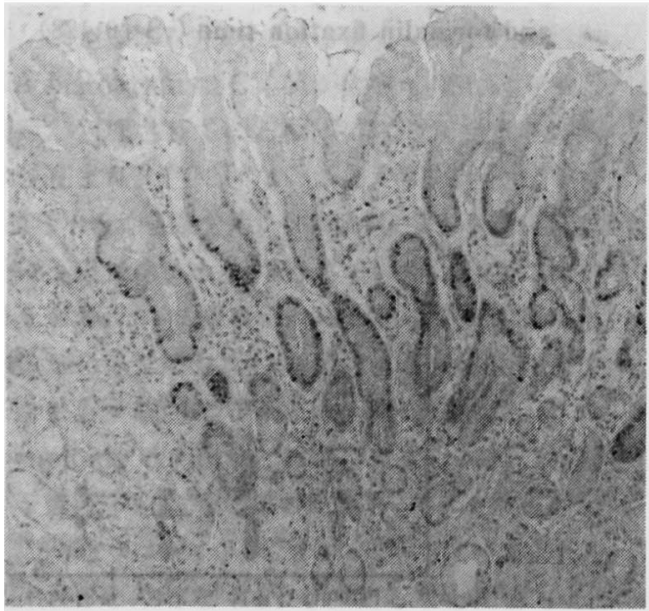

-a : normal mucosa

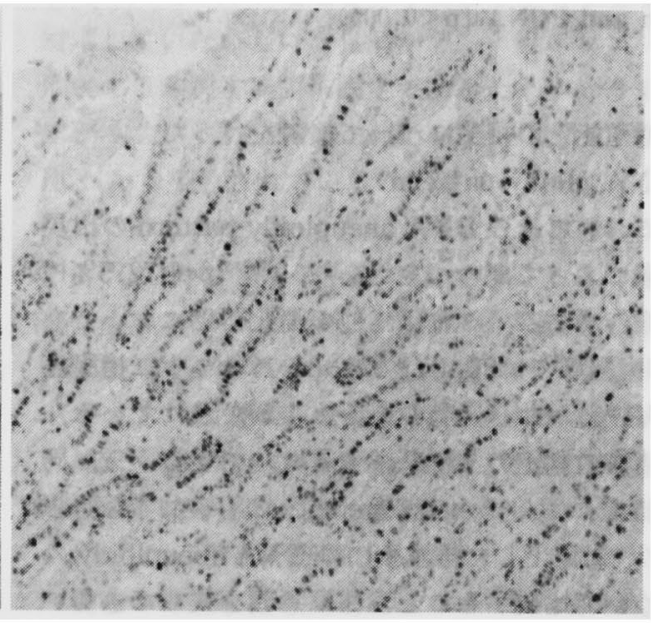

-b : tumor nest

Fig. 3 PCNA staining in normal and cancer area 


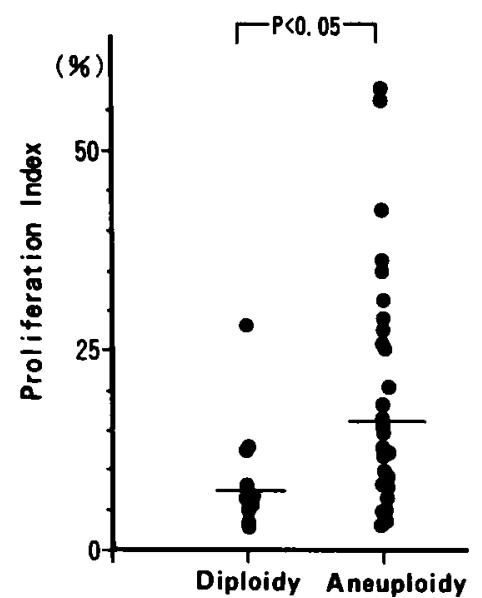

Fig. 4 Relationship between DNA ploidy pattern and PI $(\mathrm{p}<0.05)$

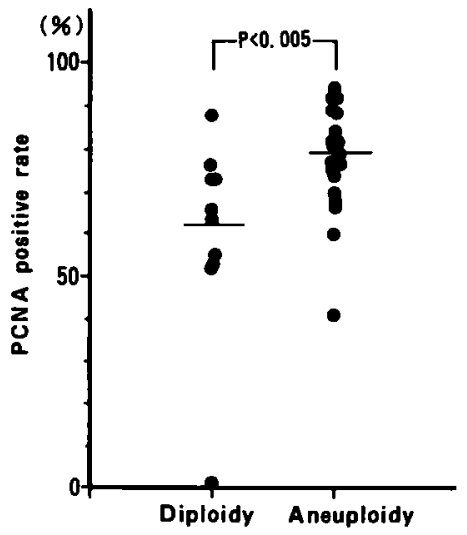

Fig. 5 Relationship between DNA ploidy pattern and PCNA $(p<0.005)$

場細胞增殖能との相関について検討を行った。

1. DNA ploidy pattern

胃癌においてその DNA aneuploidy patternの出現 率は諸家によってばらつきがあり，9\% ${ }^{15}$ から $72.5 \%{ }^{16)}$ まての報告がある。これは，他の消化器癌においても 同様で, 大腸癌では36.4\% ${ }^{177}$ か.581.1\% ${ }^{18)}$ ，十二指腸癌 では75\% ${ }^{19)}$ とかなり変動のある報告がなされている. 実際，諸家の判定方法や基㔼も異なっているら光，同 一畽瑒組織における heterogeneity の存在 ${ }^{51-9)}$ 明ら かとなり，対象とした標本の内の DNA aneuploidy の 比率について比較すること自体は意義を失ってきてい る.今回の検討では少なくとも遠位リンパ節に転移し たことと，DNA aneuploidy pattern との相関は認め

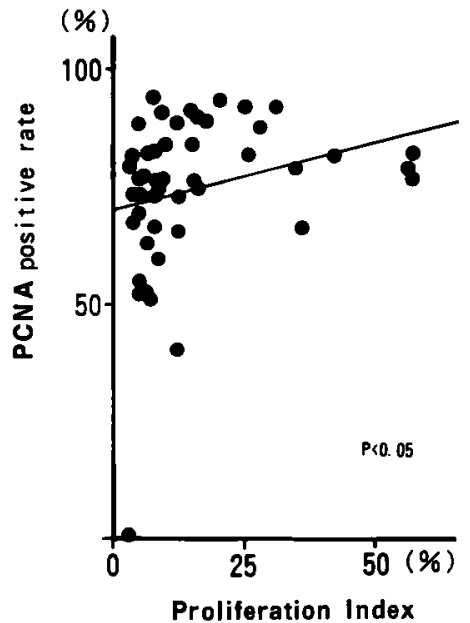

Fig. 6 Relationship between PI and PCNA ( $p<$ 0.05 )

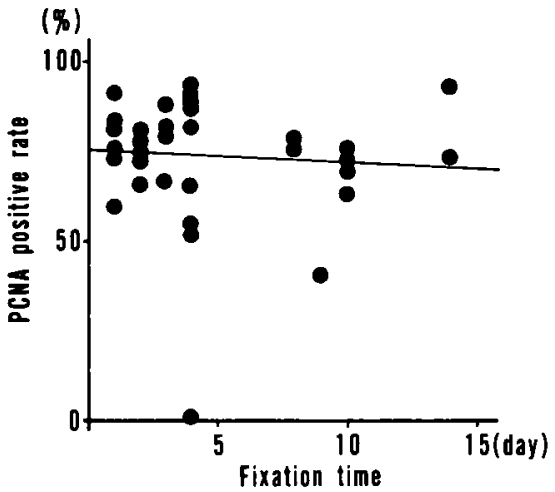

Fig. 7 Relationship between PCNA positive rate and formalin fixation time ( $\mathrm{rS}=0.128$ )

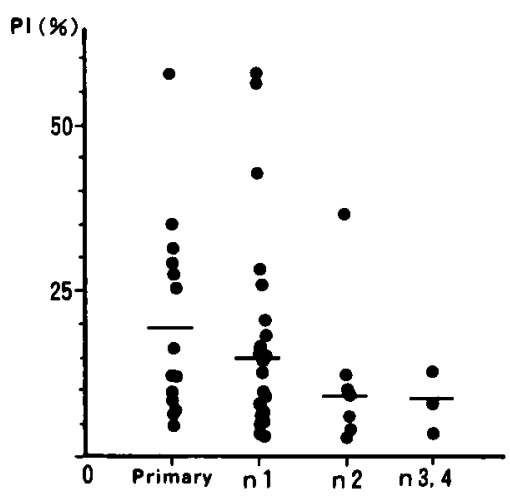

Fig. 8 Relationship between PI to n-number (metastasis to distant lymph node) 


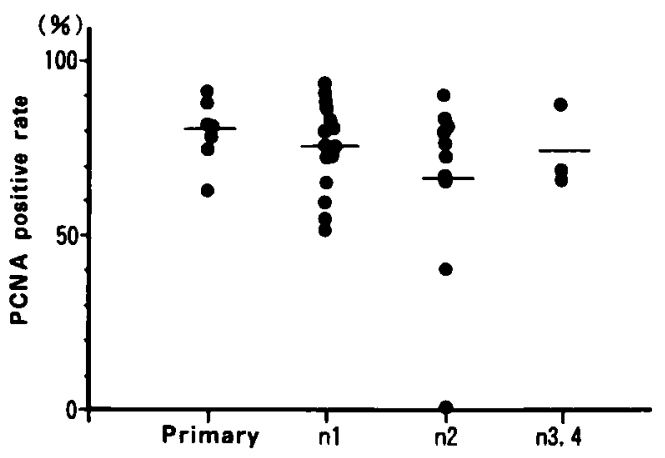

Fig. 9 Relationship between PCNA to n-number (matastasis to distant lymph node)

られなかったまた，原発巣について一切片のみの検 討であったため, 転移リンバ節の DNA ploidy pattern が異なることから原発巣での heterogeneity が示唆さ れるにとどまったが，胃癌における heterogeneityに ついてはSasaki ら”が15例中 6 例 $(40 \%)$, Aretxabala $5^{20)}$ か 37 例中 12 例( $\left.33 \%\right)$ ，松本 ( $^{8}$ か 57 例中36例 (63\%)と報告しており，今回の検討でも53\%と䄪半数 に認められ、 heterogeneityはごく普通に存在するも のと考えられた。また，同一群中の転移リンパ節にお いても heterogeneity が存在したことは，転移に際し ても腫湯細胞の各所から同一のリンハ:流への転移が起 きていることが示㖫し得るものと思われた。

\section{Proliferation index (PI)}

畽瘍細胞の覀性度の判定に対する PI 算出の有用性 も報告され゙，PIを求める簡易式についても数種の提 案があり検討されている(113/211-24!. しかし，材料として ホルマリン固定標本を用いている場合，新鮮標本に対 して DNA histogramの CV 値が大きくなることや, すでに固定, 包埋されている標本に対し，特定の増殖 期細胞は現在まだ染色できないことが問題点となって いる.小池ら゙は大腸癌を用いて検討し，PIの高い群に 有意に予後不良であったと報告している，今回の検討 では, PI と転移リンパ節 n-number との間に相関はみ られず，PIからみた限りでは増殖能によってより遠位 に転移したことを説明することは出来なかったＰIは DNA aneuploidy pattern とのあいたには有意の相関 があり，予後因子を含めて重要なバラメータの一つで あることに変わりはない.FCM の判定に対してDNA ploidy patternのみでなくPIも加えることによって， より正確な悪性度判定が可能となることも考えられ た.

\section{PCNA}

病理組織標本上において組織内増殖細胞の数や分布 を光顕的に検索し，PI と同様，基礎，臨床面で研究さ れている ${ }^{25)}$. PCNA以外にむ5-bromodeoxyuridine (BrdU) 法 ${ }^{26)}$, cell proliferation-associated human nuclear antigen (Ki-67抗体) 法27などが行われている が，BrdU 法では BrdU 抗原の前投与が必要であり， Ki-67法では，新鮮材料の凍結標本にしか利用できな いこれに対してPCNAはホルマリン固定ハラフィ ン包埋処理された標本に対しても使用可能で，簡便て あり，FCM と同様に retrospective な評価に有用と考 えられている.PCNA は全身性エリテマトーデス患者 の約 $3 \%$ ，増殖期細胞の核にのみ特異的に反応する 血中自己抗体として1978年, Miyachi ら ${ }^{28)}$ が見いたし た抗体で，G、後期からS期に合成されるDNA polymerase- $\delta$ の補助蛋白であり，DNA 合成と深くか かわっていると考えられている。この抗 PCNA 抗体 を用いて，腫瘍抗原内の発現や，他の病理組織学的因 子との関連についての娭討は少なくない291-31). しか し，簡便に利用できるだけにその問題点す幾つか指摘 されている，染色過程においてむ，固定液の問題や固 定期間 ${ }^{32}$ (3), 薄切の厚さ, 進展温度, 進展時間 ${ }^{34)}$ なに より染色率や染色態度に差が認められること，同一畽 仼内においてもその陽性所見に差がみられることや， 論理的に考えられないはどの漂漫性に陽性所見を示す ことなどである。同一庫瘍内に㧈ける陽性所見の差は 免疫染色自体の問題に加え，heterogeneityを表して いると考えることもできるが，過剩な陽性所見や陰性 所見は, PCNA が増殖という現象そのものと 1 対 1 て 対応していないという見解や35)，ィチレンブリッジを 形成する非脱水凝固系固定であるため小分子蛋白の流 出が少なく， nucleoplasmicに free に存在している PCNA も染色されているのではないかとして、これる 防ぐためにェタノール固定が有効であるという報告が ある ${ }^{32)}$.しかし今回の検討では，各標本ごとの陽性率は 高くカウントされたが，PI との間で有意の相関を示 し, 加えて，カウント方法を考虑すれば 2 週間以内の ホルマリン固定標本でも検討に値することが証明さ れ、PCNAは retrospectiveな検討を含め, 細胞の増殖 能の判定に有用であると考えられた。

\section{4.リンパ節遠隔転移と悪性度}

現在の胃癌取扱い規約上, リンハ節の群は主にリン パ流の研究から主病坚よりの距離で決定されている。 しかし，今回の検討では少なくとも，FCMにおける 
DNA ploidy pattern，PIによろ組䄉悪性度，PI およ び PCNAによる組織増殖能と，上り遠位に転移した ことの間には相関が認められなかった。

本論文の要旨は第17回癌とリン八節研究会, 第54回日本 臨床外科学会総会で発表した。

\section{文献}

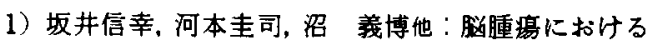
DNA aneuploidy と組䄉学的要性度との比較. ᄀ ローサイトイトリー 9:37ー41, 1989

2）木村寛伸，米村 豊, 岩作和典他：進行胃癌におけ る DNA ploidy の予後規定因子としての意義。 フ ローサイトメトリー $10: 79-85,1990$

3)山口明夫, 石田哲也, 西村元一他：核 DNA 上り た大腸癌肝転移例( FCM を用いた検討)。日外会誌 $91: 1591-1595,1990$

4）小池宏, 竹内謙二, 增田 亨他：悪性腫瑒に抢け る DNA ploidy, proliferative index の臨床的意 義. フローサイトメトリー 7:116-119, 1988

5) Teodiri L, Tirindelli $D$, Mauro F, et al: Nonsmall-cell lung carcinoma : Characterization on the basis of flow cytometrically determined cellular heterogeneity. Cytometry $4: 174-183$, 1983

6) Heppner GH: Tumor heterogeneity. Cancer Res $44: 2259-2265,1984$

7) Sakaki K, Hashimoto T, Kawachino K, et al : Intratumoral regional differences in DNA ploidy of gastrointestinal carcinomas. Cancer $62: 2569-2575,1988$

8）松本 尚, 米村 豊, 建川浩一郎他：FCMによる 胃癌原発巣内の DNA ploidy heterogeneity $と 子$ 後に成する検討.フローサイトメトリー 10:74 $-78,1990$

9 辻田和紀，舟橋公彦、渡遥正志他：大腸癌における 尰瘍内 DNA Heterogeneityに成する検討. 日本 大腸肛門病会誌 $45: 266-272,1992$

10) Schutte B, Reynders MMJ, Bosman FT, et al: Flow cytometric determination of DNA ploidy level in nuclei isolated from paraffin-enbedded tissue. Cytometry 6:26-30, 1985

11) Vindel $\phi$ v LL, Christensen IJ, Nissen NI: A detergent-trypson method for the preparation of nuclei for flow cytometric DNA analysis. Cytometry $3: 323-327,1983$

12）田川泰：ハラフィン包埋組織からの細胞分散 法. 臨㛟 34:1812-1815, 1990
13) Kawamoto K, Herz F, Wolley RC, et al : Flow cytometric analysis of the DNA distribution in human brain tumors. Acta Neuropath $46: 39$ $-45,1979$

14）胃癌研究会編：胃癌取扱い規䄪, 改討第11版，金原 出版、東京， 1985

15）諸富直文，蒲池正浩，橋本敏和：DNA-RNA 顕 虽光測光法による進行期胃癌の解析. 癌の臨 32 ： 1540,1986

16）佐々木功典，村上知之：固形腫瘍の核内 DNA 量 による娭討。臨検 $34: 692-697,1990$

17) Wolley RC, Schreiber K, Koss LG, et al : DNA distribution in human colon carcinomas and its relationship to clinical behavior. JNCI $69: 15$ $-22,1982$

18) Buchner $T$, Hidemann $W$, Wormann $B$, et al : Differential pattern of DNA aneuploidy in human malignancies. Path Res Pract 179 : 310 , 1985

19）今津浩喜, 笠原正男, 域野煡児他：十二指腸癌にお けるDNA ploidy pattem及び proliferation index と PCNA の検討。日消病会誌 89：1499 $-1505,1992$

20) de Aretxabala X, Yonemura $Y$, Sugiyama K, et al: Gastric cancer heterogeneity. Cancer 63 : 791-798, 1989

21) Ballantyne $\mathrm{KC}$, James $\mathrm{PD}$, Robin RA, et al : Flow cytometric analysis of the DNA content of gastric cancer. $\mathrm{Br} \mathrm{J}$ Cancer $56: 52-54,1987$

22) Barlogie B, Drewinko B, Johnson DA, et al: Pulse cytophotometric analysis of synchronized cells in vitro. Cancer Res 36 : 1176-1181, 1976

23) Dean PN : A simplified method of DNA distribution analysis. Cell Tissue Kinet $13: 299-308$, 1978

24) Dean PN, Gray JW, Dolbeare FA: The analy. sis and interpretation of DNA distributions measured by flow cytometry. Cytometry $3: 188$ $-195,1982$

25）向井 清：増殖細胞抗原. 病理と臨 $8: 178-185$, 1990

26) Gratzner HG : Monoclonal antibody to 5 . bromo-and 5-iododeoxyuridine a new regent for detection of DNA replication. Science 218: 474 $-475,1982$

27) Gerdes J, Schwab U, Lemke H, et al: Produc- 
tion of a mouse monoclonal antigen reactive with a human nuclear antigen associated with cell proliferation. Int J Cancer $31: 13-20,1983$

28) Miyachi K, Fritzler MJ, Tan EM : Auto antibody to a nuclear antigen in proliferating cells. J Immunol 121 : 2228-2234, 1978

29) Robbins BA, Vega D, Ogata K, et al : Immunohistochemical detection of proliferating cell nuclear antigen in solid human malignancies. Arch Pathol Lab Med 111 : 841-845, 1987

30) Matsuno Y, Hirohashi S, Furuya S, et al: Heterogeneity of proliferative activity in nodule-in-nodule lesions of small hepato cellular carcioma. Jpn J Cancer Res 81 : 1137-1140, 1990

31）佐々木功典, 村上知之, 小野定英他：フローサイト メトリーによるDNAヒストグラムと免度染色に
よる増殖細胞抗原陽性率との比較一その臨床的意

義。病理と臨 9:894-901, 1991

32）中野浩, 生田目公夫, 鈴木孝夫他：PCNAKよ る胃癌増殖活性の評価一その基礎的検討一, 日外 会誌 $93: 216,1992$

33) Hall PA, Levison DA, Woods AL, et al: Proliferating cell nuclear antigen (PCNA) immunolocalization in paraffin sections : An index of cell prolifration with evidence of deregulated expression in some neoplasm. J Path 162 : 285 $-294,1990$

34）藤森芳史，松尾恭介。松沢賢治他：胃粘膜における PCNA 染色のための固定, 薄切条件の挨討。日消 病会誌 $88: 1921,1991$

35）堤寞：各種自己抗体を応用した疾患の検討。 病理と臨 $4: 295-301,1986$

\title{
A STUDY OF DNA PLOIDY PATTERN, PROLIFERAION INDEX AND PROLIFERATING CELL NUCLEAR ANTIGEN (PCNA) IN PRIMARY AND METASTATIC TUMORS IN ADVANCED GASTRIC CARCINOMA
}

\author{
Hiroki IMAZU, Takahiko FUNABIKI, Masahiro OCHIAI, Yoshihisa MARUGAMI, Kohji NAKAMURA, \\ Hiroshi FUKUI, Katsuhiko KAMEI, Hisashi YAMAGUCHI, Shigeru HASEGAWA, \\ Kazuhumi ARAI, Kikuo MORI and Masao KASAHARA* \\ Department of Surgery and First Department of Pathology*, Fujita Health University School of Medicine, Aichi, Japan
}

Fifth-five materials including primary lesions and lymph node metastasis from 15 cases of advanced gastric carcinoma were evaluated for DNA ploidy patterns, proliferation index (PI), proliferating cell nuclear antigen (PCNA).

1) DNA aneuploidy pattern was found in 43 out of 55 materials (78\%).

2) Heterogeneity on DNA histogram was observed in 8 cases (53\%).

3) PCNA staining was positive in 53 materials $(96 \%)$.

4) DNA ploidy pattern was revealed to correlate significantly to $\mathrm{PI}(\mathrm{p}<0.05)$ and PCNA positive rate $(\mathrm{p}<0.005)$.

5) PI was revealed to correlate significantly ( $\mathrm{p}<0.05, \mathrm{rS}=0.345$ ) to $\mathrm{PCNA}$ positive rate.

6) Fixation time did not effect in PCNA staining rate at least within 2 weeks.

7) No correlation of DNA ploidy pattern, PI, or PCNA positive rate to n-number (metastasis to distant lymph node) could be detected.

From these findings, no correlation between probable distant lymph node metastasis and the degree of malignanicy and proliferating activity due to these parameters were able to be proved. For this, possible participation of heterogeneity can be inferred. 